Habitats in Britain (Poyser/Buteo; $£ 13$, \$35). The author, Rob Fuller, was responsible for organization of the national survey and he has drawn not only on its results but on many other sources to describe the composition of bird communities in different habitat types: he also comments on the pressures from current land-uses, notably agriculture and forestry which are the major modifiers of habitats and thus the greatest threat to a number of British species.

A mapping exercise of a different character is represented by Colin Harrison's Atlas of the Birds of the Western Palaearctic (Collins/Princeton University Press; $£ 12.95, \$ 25$ ) which shows the summer, winter and resident distribution of all species normally occurring in Europe, North Africa and the Middle East. The text gives accounts of each species' status, climatic range, typical habitats and sites and there are pleasant, if rather irrelevant, half-tone drawings of the species concerned on each page. The layout and presentation are clear and the work provides a partial up-date of Voous' masterpiece, Atlas of European Birds, now 20 years old. Perhaps inevitably in such a complex exercise, there are mapping errors but, used with care, the book will be of value, not least to the select band of birders who seek to pursue their hobby wherever birds themselves go.

John Andrews is Head of Conservation Planning at the Royal Society for the Protection of Birds, Sandy, Bedfordshire.

\section{Africa's avifauna}

\section{C.M. Perrins}

The Birds of Africa, Vol. 1. By Leslie H. Brown, Emil K. Urban and Kenneth Newman. Pp.536. ISBN 0-12-137301-0. (Academic: 1982.) £53.40, \$99.

No wORK covering the birds of the whole of Africa has been published for over 20 years. The Birds of Africa is intended to remedy this state of affairs, and when completed will comprise at least five volumes (with the possibility of a further one to include the birds of Malagasy and the Indian Ocean).

This, the first volume, deals with 10 orders of non-passerine birds from ostriches to birds of prey, some 270 species in all. It starts with 31 useful pages of general information on the geology, climate, geography and habitats of Africa, and with an introduction to the avifauna, the number of species involved and their migrations.

In the main part of the book the information given for each species is fairly standard handbook material, with details of range and status, description, field characters, voice, general and breeding habits and food, together with a distribution map and one or more pictures on the colour plates. On average some $11 / 2$ pages is allotted to each bird, though a few well-known species (such as the ostrich) get as many as five pages and a few of the vagrants only a few lines. Throughout the book the writing is clear and informative, and emphasizes field biology, especially ecological and behavioural studies, the latter often including line-drawings to amplify the text.

Although the standard of presentation is high, there are some shortcomings. For instance the distribution maps raise a few problems. Many in other handbooks show summer and winter ranges. This is more difficult when dealing with African birds because different areas experience such very different seasons. Ideally, however, it ought to be possible to depict breeding and non-breeding distributions and it is a little disappointing that this has not been done, except in a very few cases. In addition there is some inconsistency - albeit minor - in the treatment of distributions of the birds of offshore islands and in mapping bird distributions in Malagasy.

Bird books often stand or fall by the quality of their illustrations, but here the plates - by Peter Hayman and Martin Woodcock - are well up to standard. Some of the paintings are on the small side; in the extreme case there are over 70 birds on a single page. However on the whole they are acceptable because of the large format of the book, and as a group they succeed remarkably well in being both accurate and aesthetically pleasing. For most species there are at least two pictures showing the different sexes or summer and winter plumages; in addition there is often a painting of a young bird.

One minor worry concerned the amount of space available for each species. The dust-jacket states that there will be a further three volumes. However, this first volume includes only about 270 of the 1,850 or so species recorded in Africa. Hence the remaining three volumes would have had to cover 1,600 species, or twice as many per book as Vol.1. Even granted that this volume contains many of the betterknown birds, such as the ducks and birds of prey, this would have been difficult. Fortunately the publishers have recently decided that there will be at least one further volume; this will ease things considerably.

The Birds of Africa, an immense project, was the brain-child of Leslie Brown who sadly died before this volume was completed. One very much hopes that the other authors will maintain his drive since the completed work will be a valuable contribution to ornithology.

Christopher Perrins is Director of the Edward Grey Institute of Field Ornithology, Department of Zoology, University of Oxford.

\section{A world of far away and long ago}

\section{Andrew Hill}

The Historia Naturalis of Pliny the Elder. By Joyce Irene Whalley. Pp.46. ISBN 0-283-98905-X. (Sidgwick \& Jackson: 1982.) $£ 6.95$.

PROPPED between two slaves poor Pliny died, while the pumice of Vesuvius fell about him. It was his constant search for facts that led to this early demise, a compulsion that had produced a number of books on a range of subjects, now all lost but for the encyclopaedic Historia Naturalis. This work justly purported to encompass ". . . the world of Nature, or, in other words, Life . . .", and assembled what Pliny calculated as 20,000 facts, culled from 2,000 other books and his own experience. Including places, peoples, animals, plants, geology, medicine, painting, it provides a rich view of the world in the first century $A D$. This is a significant view, for it was one that with all its faults and pseudodoxies dominated Europe through the Middle Ages and extended its influence to more recent times.

Joyce Whalley's fascinating work is rather less ambitious, being intended primarily as a picture book. In the 1460 s Giuliano Amedei illustrated a manuscript of Pliny with elaborate historiated initials for each of the 37 books or chapters. These depicted scenes related to the subject matter, and occasionally are as fanciful as parts of the text. One, for instance, shows a varied assemblage of humanoids, including the rare umbrella-foot tribe who, disposing themselves upon their backs, avoid the sun's glare through the protection afforded by the shadows of their substantial feet.

Some of these beautiful illustrations, highly ornamented in white vine decoration, resemble secular aspects of the contemporary books of hours, being lively and realistic treatments of everyday fifteenth-century activities. Many also reflect Pliny's patchy accuracy: elephants have lions' feet, and even more readily observable insects have eight or more legs.

Amedei comments visually on Pliny; Joyce Whalley comments on them both. Short descriptive sections opposite each plate indicate their significance, giving a necessarily brief account of the appropriate chapter and selecting phrases, practices and beliefs that have some particularly modern association. This pleasant and enjoyable book provides a vivid and instructive glimpse of the world through earlier eyes. It is also an enticement to explore in more detail the complete work, forming a gentle introduction to the cosmos and nature of Pliny.

Andrew Hill is a Research Fellow at Harvard University. 